\title{
Engagement in quality improvement and patient safety - novel solutions proposed by UK-based medical students
}

This article was published in the following Dove Press journal:

Advances in Medical Education and Practice

23 January 2017

Number of times this article has been viewed

\author{
Saeed Azizi' \\ Faisal Siddiqui' \\ Ithsham Iqbal' \\ Ibtesham Tausif Hossain ${ }^{2}$ \\ 'Faculty of Medicine, St. George's \\ Hospital Medical School, ${ }^{2}$ Faculty \\ of Medicine, Imperial College, \\ London, UK
}

Correspondence: Saeed Azizi Faculty of Medicine, St. George's Hospital Medical School, Cranmer Terrace, London, SWI7 ORE, UK

Email saeedazizi.sa@gmail.com

\section{Dear editor}

We have read Nair et al's recent article ${ }^{1}$ with great interest, on the medical student perspective of quality improvement (QI) teaching at medical school. We agree that through improved teaching and engagement, medical students would become enabled to carry out their own QI projects. As fellow medical students, we would like to offer our perspective on how this could be implemented into the curriculum to ensure that it is a part of the key skill set of every student.

The authors detail that from their experience a combination of both structured teaching and active participation is important in teaching QI. We also agree that this structured teaching should be introduced at a much earlier stage in medical school. This would allow for a much more gradual transition from peripheral involvement to central participation. After students have developed an understanding of QI, they can then consolidate this in the later years of medical school before going out and participating in QI in a clinical context. This gradual, stepwise teaching approach fits in line with Kolb's experiential learning cycle of reflective observation, abstract conceptualization, active implementation, and concrete experience. ${ }^{2}$

Whether the audience in question are medical students or doctors, the key issue of engagement still remains. We propose a model that would systematically improve the participation of students in QI. In our model, we put emphasis on three key areas: engagement, consolidation, and implementation.

In the first key area, the emphasis in the preclinical years of medical school would be to introduce the concept of QI and engage students through lectures and studentselected component opportunities. With many well-known organizations now involved in health care QI, it would certainly be feasible to hold interactive sessions that could be both exciting and engaging for students - opening their eyes to the diversity of means available to engage with QI, such as smartphone applications, system changes, equipment advancements, and so on. ${ }^{3,4}$ This early exposure to QI would lead to the second key area of consolidation - achieved by incorporating QI in case-based discussions or allowing students to be involved in uncomplicated QI projects, facilitated by universities or student-led societies.

Once students reach the clinical years of medical school, the focus would shift to the third key area of implementation. Having already developed a basis of QI knowledge, students could then get more centrally involved in projects - perhaps organizing their 
own projects and presenting their work. By the time these students graduate as doctors they would already have the skills and confidence to carry out QI work, and would have also gained an insight into important QI skills such as leadership, stakeholder analysis, process mapping, and more, all of which will contribute to them being able to successfully implement change. Students can then focus on more complex topics, such as sustainability, cost-effectiveness, and transferability. When moving toward complex skills, it will be important to implement strategies that scaffold student learning, applying Vygotsky's zone of proximal development. ${ }^{5}$

From our experience as medical students, the emphasis on the importance of QI is unsatisfactory in medical school and we feel that implementation of the above model improves this. It provides a framework to address the inadequate exposure to QI during medical school highlighted by Nair et al. Currently, it seems as though QI is largely a concept that is introduced very late on and often serves as a tick-box exercise; but by focusing on early engagement and consolidation, followed by the gradual transition to implementation, students will gain the necessary tools to both understand and implement QI in a health care setting. Embedding the importance of QI as a principle is something students can utilize throughout their health care career. Aside from fulfilling the General Medical Council's requirements of QI activity in appraisal and revalidation for doctors, ${ }^{6}$ this will also have a positive impact on patient safety and the quality of health care provided.

\section{Disclosure}

The authors report no conflicts of interest in this communication.

\section{References}

1. Nair P, Barai I, Prasad S, Gadhvi K. Quality improvement teaching at medical school: a student perspective. Adv Med Educ Pract. 2016;7:171-172.

2. Kolb DA. Experiential Learning: Experience as The Source of Learning and Development. Englewood Cliffs, NJ: Prentice Hall, Inc.; 1984:20-38.

3. IBM. Using analytics and collaboration to improve healthcare quality and outcomes. 2015. Available from: http://www-01.ibm.com/common/ ssi/cgi-bin/ssialias?htmlfid=IMW14650USEN. Accessed December 5, 2017.

4. Cisco. Healthcare - Cisco. 2016 (Online). Available from: http://www. cisco.com/c/en/us/solutions/industries/healthcare.html. December 5, 2017.

5. Sanders D, Welk DS. Strategies to scaffold student learning: applying Vygotsky's Zone of Proximal Development. Nurse Educ. 2005;30(5): 203-207.

6. General Medical Council. Supporting information for appraisal and revalidation. 2012. Available from: http://www.gmc-uk.org/RT__Supporting_information_for_appraisal_and_revalidation__DC5485. pdf_55024594.pdf. Accessed December 5, 2017.

\section{Publish your work in this journal}

Advances in Medical Education and Practice is an international, peerreviewed, open access journal that aims to present and publish research on Medical Education covering medical, dental, nursing and allied health care professional education. The journal covers undergraduate education, postgraduate training and continuing medical education including emerging trends and innovative models linking education, research, and health care services. The manuscript management system is completely online and includes a very quick and fair peer-review system. Visit http://www.dovepress.com/testimonials.php to read real quotes from published authors. 